\title{
The Wonder of Birds: What They Tell Us About Ourselves, the World, and a Better Future. By Jim Robbins. 2017. Spiegel and Grau, Penguin Random House, New York. 352 pp.
}

\author{
Nicole Sault ${ }^{1 *}$ \\ ${ }^{1}$ Sally Glean Center, Palo Alto, California. \\ *nicole@sallyglean.org
}

Received September 13, 2018

Accepted November 11, 2018

OPENӘACCESS

DOI 10.14237/ebl.9.2.2018.1404

Copyright (C) 2018 by the author(s) licensee Society of Ethnobiology. This is an open-access article distributed under the terms of the Creative Commons Attribution-NonCommercial 4.0 International Public License (https://creativecommons.org/licenses/by-nc/4.0), which permits non-commercial use, distribution, and reproduction in any medium, provided the original author and source are credited.

This book explores the mystery and beauty of birds. There are chapters full of suspense- exploring avian enigmas such as flocks synchronizing their movements in murmurations, chickadees transferring complex information using calls with syntax, and migrations of Arctic terns traveling 12,000 miles. Other chapters provide fascinating detail on the aerodynamics of feathers that transmit information through skin attachments, avian eyesight with ultraviolet perception and magnetoreception, and extreme physiology that enables birds to endure great heights and depths with freezing temperatures. The author's love for birds shines throughout the book and he writes in an engaging style. Each chapter begins with an elegant illustration by D.D. Dowden and quotes from Dickinson, Thoreau, John Lennon, and Mehmet Murat Ildan. Unfortunately, the scientific names of the birds are not included.

The author describes what birds provide through food, feathers, dispersal of seeds and pollen, reducing insect pests, and guidance to people with advice or warnings. Birds "maintain ecosystem function and resilience" by "balancing the world" (pp. 109; 114). Robbins wants people to understand and appreciate birds because people conserve what they love. He addresses the types of emotional connection people have with birds and their power to heal. Through "Wings Over America," at-risk teens and imprisoned youth in Washington, D.C. are introduced to falcons and taught how to protect these magnificent birds.

Yet, Robbins laments that we have lost a sense of the sacred-of the cosmic egg as the origin of the world (pp. 81-83). The royal rooster has become a commodity and suffers at human hands. The actual costs of factory farmed chicken are hidden by keeping consumers unaware of the inhumane treatment of the chickens, the workers, the farmers who work as sharecroppers living below the poverty line, and the manure that pollutes land and water, leading to dead zones at sea (pp. 84-85).

A central problem of the book is that the author does not follow through on the goals he sets and contradicts his stated aim. The preface argues that "It's time to be more inclusive and more creative, to peer beneath the surface to vastly broaden our scope, to consider other ways of seeing and being in the world, and to reframe our perspective of nature, which will ultimately make us a far more resilient species" (p. xviii). He calls for an ethno-ornithological approach that can deepen our relationship to birds through Indigenous teachings.

However, after claiming that birds offer us alternative perspectives on the world and the issues we face, he then expounds on the material benefits birds offer. Although the details of bird anatomy and behavior are intriguing, he justifies appreciation for birds by describing how this knowledge of birds can be used for medicine and engineering, such as understanding brain function and designing better planes and trains or paint (p. 26). He seems to believe people will appreciate birds because they are usefulfor search and rescue missions (p. 239), for preventing or treating disease (p. 217), and reducing pests (p. 222). The author also ignores the pet trade 
and the political context of avian research, such as government funding for research that is later used for warfare (e.g., drone technology).

While Robbins presents fascinating interviews with experts engaged in complex research, a second problem with the book is that he strays into technical areas where he lacks the ability to assess the credibility of the claims put forward in primatology, evolutionary theory, human genetics, neurophysiology, psychiatry, linguistics, and kinship. At times he presents the findings of a particular investigator without discussing contradictory evidence and competing theories that both ethno-ornithology and anthropology could provide.

For example, in Chapter 13, The Bee-eaters: A Modern Family, he digresses into a long discussion of human families, stepparents, incest, genetic testing and the selfish gene theory, and loses his way in the halls of genetic determinism. Regarding the great apes he states that they "do not time travel mentally" and are "slaves, in essence, to a perpetual now" (p. 161). How does he know this? As there are no footnotes or references, it is difficult to evaluate such claims that ignore abundant evidence to the contrary. His evidence is so selective that it could mislead readers who lack the scientific background for evaluating the arguments, as alternative interpretations are omitted, including environmental or cultural factors.

In Chapter 17, The Transformational Power of Birds, he analyzes the attraction of bird watching in relation to the psychology of repressed fear. Explaining interest in birds as fear of death and the desire for immortality is unconvincing, as the cultural associations of birds vary, and the same bird species may represent death in one society and life in another. Some people fear owls, for example, while others treasure them as guardians. It would be enlightening if instead of interviewing so many university researchers he devoted greater space to Indigenous knowledge. He traveled to the Flathead Indian Reservation in Montana to talk to a field biologist studying owls and describes this man's research and personal history with birds, but never asks any of the local people about what owls mean in their culture or for them personally.

The spiritual dimensions of birds and their symbolic meaning cross-culturally are left until the end, and the discussion fails to explore the implications for taking such perspectives seriously. When he relates bird myths of the Mapuche and Yaghan in Chile that portray the need for cooperation, he misses the point. These myths are not only about reciprocity in relationships between humans, but about relationships between humans and other beings, including birds. Kinship is the model for these relationships, which implies responsibilities toward them. When people say they are related to birds this is not simply metaphorical, but represents a greater reality that Indigenous peoples apprehend as spiritual.

The most poignant section of the book relates how the Kaluli of Indonesia map their world through birdsong. Anthropologist Steven Feld portrays this as a form of crying with poetry. Stories are sung from the point of view of each species of bird flying through the forests and valleys (p. 218-219). These birds are held to be ancestors who carry the spirits of departed relatives to the next world. The Kaluli regard the birds so highly that they protect a tract of forest where no hunting is allowed, so that the birds may flourish. But Exxon is now building a gas pipeline in the region (p. 219). How will the birds and the ancestors respond?

These stories about the need to cooperate and share lead to the question: What are we doing for birds? They bring us countless gifts, yet what do we give them? Providing a chapter on actions people could take to address these issues, and documenting successes in protecting birds would have been helpful, for after reading about the enormous threats to bird survival, the reader is left with an overwhelming sense of frustration and helplessness. 